Article

\title{
Catalytic Advanced Oxidation Processes for Sulfamethoxazole Degradation
}

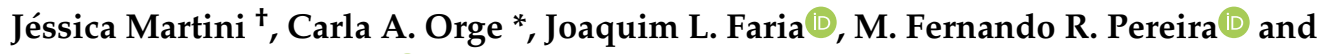 \\ O. Salomé G. P. Soares * \\ Laboratory of Separation and Reaction Engineering-Laboratory of Catalysis and Materials (LSRE-LCM) \\ Faculdade de Engenharia, Universidade do Porto, Rua Dr. Roberto Frias s/n, 4200-465 Porto, Portugal \\ * Correspondence: carlaorge@fe.up.pt (C.A.O.); salome.soares@fe.up.pt (O.S.G.P.S.) \\ + Current address: Centro de Tecnologia-Departamento de Engenharia Sanitária e Ambiental, \\ Universidade Federal de Santa Maria, Avenida Roraima, n 1000, 97105-900 Santa Maria, Brasil.
}

Received: 30 April 2019; Accepted: 25 June 2019; Published: 29 June 2019

\begin{abstract}
The degradation of sulfamethoxazole (SMX) by several advanced oxidation processes (AOPs) is carried out in the presence of different catalysts. The catalysts used consisted of carbon nanotubes $(\mathrm{CNT})$, titanium dioxide $\left(\mathrm{TiO}_{2}\right)$, a composite of carbon nanotubes and titanium dioxide $\left(\mathrm{TiO}_{2} / \mathrm{CNT}\right)$, and iron supported on carbon nanotubes (Fe/CNT). SMX removal was evaluated by catalytic ozonation, photocatalysis, catalytic oxidation with hydrogen peroxide, and combinations of these processes. The evolution of the SMX concentration during reaction time, the mineralization degree, the toxicity of the treated solution, and the formation of organic intermediates and ions were monitored. Ozonation catalyzed by Fe/CNT and CNT and photocatalytic ozonation in the presence of CNT presented the fastest degradation of SMX, whereas photocatalytic ozonation with CNT showed the best results in terms of organic matter removal (92\% of total organic carbon (TOC) depletion). Total mineralization of the solution and almost complete reduction of toxicity was only achieved in the photocatalytic ozonation with $\mathrm{H}_{2} \mathrm{O}_{2}$ and Fe/CNT catalysts. The compound 3-amino-5-methylisoxazole was one of the first intermediates formed during SMX degradation. p-Benzoquinone was only formed in photocatalysis. Oxalic and oxamic acids were also detected and in most of the catalytic processes they appeared in small amounts. Ion concentrations increased with the reaction time.
\end{abstract}

Keywords: catalytic ozonation; photocatalysis; hydrogen peroxide; emerging pollutants; carbon nanotubes; titanium dioxide

\section{Introduction}

Advanced oxidation processes (AOPs) are based on the oxidation of organic pollutants by strong oxidizing species, notably hydroxyl radicals $\left(\mathrm{HO}^{\bullet}\right)$, which react rapidly and indiscriminately with several organic compounds. Their main objective is to mineralize the pollutants into carbon dioxide and water, or convert them into by-products, sometimes less harmful to human health and the aquatic environment [1]. These processes have been shown as an effective alternative to the removal of persistent compounds, such as hormones, drugs, and pesticides.

In the presence of catalysts, it is expected that the oxidation capacity of the processes will increase and, consequently, the degradation of the main pollutant and intermediates would be easily attained, leading to higher levels of mineralization. Catalytic reactions can be homogeneous or heterogeneous, wherein solution and catalyst are in the same phase, or in distinct phases, respectively.

Carbon-based catalysts are widely studied and presented good results in catalytic ozonation reactions [2-7]. There are different suggestions of reaction mechanisms for ozonation catalyzed by carbon materials. Some studies have suggested that carbon material acts as the initiator of $\mathrm{O}_{3}$ 
decomposition, producing $\mathrm{H}_{2} \mathrm{O}_{2}$ and, consequently $\mathrm{OH}^{\bullet}$ in solution $[2,5,8,9]$. On the other hand, some researchers suggested that $\mathrm{O}_{3}$ adsorption and reaction on the carbon surface led to the formation of free radicals which can react with organic species $[3,5,10]$. Furthermore, $\mathrm{OH}^{\bullet}$ present in solution and those on the surface of the material may contribute to the mineralization of the compounds [11]. The efficiency of the catalytic ozonation process depends on the chemical and textural properties of the catalyst, as well as on the temperature and $\mathrm{pH}$ of the solution. Usually, the higher surface area of the carbon material leads to better $\mathrm{O}_{3}$ decomposition [11]. Furthermore, delocalized $\pi$ electrons on the carbon nanotube (CNT) surface are known to be active sites for the decomposition of $\mathrm{O}_{3}$ and radical formation [4]. On the other hand, acidic CNTs present lower catalytic activity, because the electron density is more moderate, resulting in fewer electrons on the surface to react with $\mathrm{O}_{3}$-despite exhibiting high content of oxygenated surface groups and delocalized $\pi$ electrons [4]. The decomposition of $\mathrm{O}_{3}$ in water also strongly depends on the $\mathrm{pH}$ of the solution, because the $\mathrm{pH}$ increase enhances the decomposition of $\mathrm{O}_{3}$ and, also, the surface properties of the catalysts can be modified [12].

Photocatalytic reactions arise from the combination of photolysis with a catalyst, in this case, named as photo-catalyst. The photo-catalyst should be photoactive, capable of responding to visible and/or UV light, biologically and chemically inert, photo-stable, and non-toxic $[13,14]$. Photocatalysts are typically materials that have a band gap energy between the valence band (VB) and conduction band (BC). However, in some conditions, the electrons are promoted from VB to BC generating an electron-hole pair $\left(\mathrm{e}^{-} / \mathrm{h}^{+}\right)$, thus presenting electrical conductivity, and can act as an electron donor or acceptor $[15,16]$. The most used photo-catalyst is $\mathrm{TiO}_{2}$ because it is not toxic, chemically stable, and inexpensive [15]. Composites with $\mathrm{TiO}_{2}$ and $\mathrm{CNT}$ are an interesting alternative in photocatalytic reactions since it is expected that the use of $\mathrm{TiO}_{2} / \mathrm{CNT}$ composites reduces the recombination of the pair $\mathrm{e}^{-} / \mathrm{h}^{+}$, because the excited electron of the conduction band of $\mathrm{TiO}_{2}$ can migrate to the CNT $[17,18]$. Another aspect is that the presence of Ti-O-C linkages increases light absorption, leading to an increase in the photocatalytic activity. Also, the presence of CNT contributes to a rise in the surface area of the composite, thereby increasing the available active centers when compared with pure $\mathrm{TiO}_{2}[19,20]$. In spite of photocatalysis being mainly used in organic pollutant degradation, removal of heavy metals was also investigated [21]. The sequence of two solar photocatalytic processes $\left(\mathrm{TiO}_{2}\right.$ photocatalysis in the presence of $\mathrm{O}_{2}$ followed by the presence of $\mathrm{N}_{2}$ ) was proven to be efficient in the removal of copper, iron, and zinc presented in real soil washing effluents. The results indicate that wastewaters can be successfully treated under a natural sunlight source, although it requires more time to reach significant pollutant removal efficiencies than simulated irradiation.

When photolysis, ozonation, and an appropriate catalyst are combined, the catalyst is photo-excited through radiation and $\mathrm{O}_{3}$ molecules can adsorb on the catalyst surface, resulting in the production of active oxygen radicals $\left(\mathrm{O}^{\bullet}\right)$. Another advantage is that the presence of $\mathrm{O}_{3}$ decreases the recombination of the pair $\mathrm{e}^{-} / \mathrm{h}^{+}[22]$.

Catalytic reactions involving hydrogen peroxide $\left(\mathrm{H}_{2} \mathrm{O}_{2}\right)$ are mainly promoted by the addition of transition metals with high valence, such as Ti, $\mathrm{V}, \mathrm{Mo}, \mathrm{W}$, and Re [23]. The formation of hydroxyl radicals by $\mathrm{H}_{2} \mathrm{O}_{2}$ can also be promoted by Fenton reaction or photo-Fenton, whose catalytic process is based on electron transfer between a cationic metal and $\mathrm{H}_{2} \mathrm{O}_{2}$. In this process, $\mathrm{Fe}^{2+}$ acts as a catalyst and combined with $\mathrm{H}_{2} \mathrm{O}_{2}$ under acid conditions produces reactive species, especially $\mathrm{OH}^{\bullet}$ radicals. Furthermore, the photo-Fenton process presents improved efficiency due to the formation of additional amounts of $\mathrm{OH}^{\bullet}$ radicals through photoreduction of the iron ions formed during the Fenton reaction, since the photoreduction leads to regeneration of these ions to complete the catalytic cycle [24]. This improvement was confirmed by Malato et al. during the degradation of three pesticides (imidacloprid, methomyl, and formetanate) under solar radiation [25]. The homogenous photo-Fenton process revealed to be more efficient than photocatalysis in the presence of $\mathrm{TiO}_{2}$ in terms of pollutant removal, mineralization degree, and toxicity reduction.

This work aims to study the degradation of sulfamethoxazole (SMX) by catalytic advanced oxidation processes. SMX is a synthetic antibiotic of the sulfonamides group commonly used to 
treat respiratory and urinary diseases caused by bacteria [26]. Additionally, SMX is also used in agriculture as herbicide and in preventive care in veterinary medicine [27]. This antibiotic is found in waterbodies in small concentrations, but its presence in the environment can cause extensive damage to aquatic organisms, especially the emergence of resistant bacteria $[28,29]$. There is no doubt about the occurrence of sulfamethoxazole (SMX) as a pollutant in several aquatic instances around Europe. According to Bila et al., SMX was detected in Germany in the range 300-1500 ng L ${ }^{-1}$ and $0.4 \mu \mathrm{g} \mathrm{L}{ }^{-1}$ in wastewater treatment plants, $30-85 \mathrm{ng} \mathrm{L}^{-1}$ and $0.03 \mu \mathrm{g} \mathrm{L}^{-1}$ in surface waters, and $410 \mathrm{ng} \mathrm{L}^{-1}$ in underground waters [30]. Gaffney et al. reported the presence of SMX in drinking waters (approximately $22 \mathrm{ng} \mathrm{L}^{-1}$ ) in the Netherlands and USA [31]. In Portugal, the presence of SMX was also confirmed. According to the report performed by Madureira et al., SMX was detected in concentrations around $53.3 \mathrm{ng} \mathrm{L}^{-1}$ in the Douro river, $0.27 \mathrm{ng} \mathrm{L}^{-1}$ in drinking waters, and $8.0 \mathrm{ng} \mathrm{L}^{-1}$ at the sampling point in the Tagus river [32]. As SMX is a persistent contaminant, it is not easily degraded by conventional treatment processes, requiring the application of advanced techniques. Therefore, the following catalytic advanced processes were studied to enhance the degradation of SMX: photocatalysis (L), catalytic ozonation $\left(\mathrm{O}_{3}\right)$, and catalytic oxidation with hydrogen peroxide $\left(\mathrm{H}_{2} \mathrm{O}_{2}\right)$. The combination of two or more processes-photocatalytic ozonation $\left(\mathrm{L} / \mathrm{O}_{3}\right)$, photocatalysis with hydrogen peroxide $\left(\mathrm{L} / \mathrm{H}_{2} \mathrm{O}_{2}\right)$, catalytic ozonation with hydrogen peroxide $\left(\mathrm{O}_{3} / \mathrm{H}_{2} \mathrm{O}_{2}\right)$, and photocatalytic ozonation with hydrogen peroxide $\left(\mathrm{L} / \mathrm{O}_{3} / \mathrm{H}_{2} \mathrm{O}_{2}\right)$ - for the degradation of SMX were also carried out. The processes cited above were also studied in detail in the absence of catalysts [33].

The main subject of this research is to study the degradation of sulfamethoxazole by different oxidation processes and in the presence of various catalysts. For that propose, four solid-state materials with optical semiconductor properties were used as catalysts and they were extensively characterized to better understand their performance. Carbon nanotubes (CNT) were chosen due to their strong catalytic activity with $\mathrm{O}_{3}$, especially for promoting the $\mathrm{O}_{3}$ decomposition and surface reactions. Titanium dioxide $\left(\mathrm{TiO}_{2}\right)$ was used due to its stability and photocatalytic activity which promote the formation of oxidative radicals in the presence of light. A composite of carbon nanotubes and titanium dioxide $\left(\mathrm{TiO}_{2} / \mathrm{CNT}\right)$ was chosen because it can improve the reaction in the presence of light, once it avoids the recombination of the pair $\mathrm{e}^{-} / \mathrm{h}^{+}$and enhances the activity of $\mathrm{TiO}_{2}$. Finally, iron supported on carbon nanotubes $\left(\mathrm{Fe} / \mathrm{CNT}\right.$ ) were used since $\mathrm{H}_{2} \mathrm{O}_{2}$ can be decomposed in the presence of $\mathrm{Fe}$, generating radicals. Since this work does not consider only photo-based processes and it is not a net photochemistry study, detailed photophysical information was not evaluated. The efficiency of various processes was critically compared in terms of SMX concentration, mineralization level, and formation of intermediate compounds (3-amino-5-methylisoxazole-AMI, p-benzoquinone-BZQ, oxamic acid-OXM, and oxalic acid-OXL) and ions (sulphate- $\mathrm{SO}_{4}{ }^{2-}$, nitrate $-\mathrm{NO}_{3}{ }^{-}$, and ammonium $-\mathrm{NH}_{4}{ }^{+}$).

\section{Materials and Methods}

\subsection{Reagents}

Ammonium chloride ( $\geq 99 \%$ ), hydrogen peroxide (wt $30 \%$ ), iron (III) nitrate nonahydrate $(\geq 98 \%)$, methanol $(\geq 99.8 \%)$, nitric acid $(90 \%)$, oxalic acid $(\geq 99 \%)$, oxamic acid $(\geq 96 \%)$, sodium carbonate $(\geq 99 \%)$, sodium nitrate ( $\geq 99 \%$ ), sulfamethoxazole ( $\geq 99 \%$ ), titanium (IV) isopropoxide $(97 \%)$, p-benzoquinone ( $\geq 99.5 \%)$, 2,6-pyridine dicarboxylic acid ( $\geq 99 \%$ ), and 3-amino-5-methylisoxazole $(\geq 98 \%)$ were provided by Sigma Aldrich (Saint Louis, MO, USA). Anhydrous sodium sulfate ( $\geq 99 \%)$ was acquired from Riedel-de Haën (Seelze, Germany), multiwalled carbon nanotubes (CNT) ( $\geq 95 \%$ C) from Nanocyl, ethanol (99.8\%) from PanReac, sodium nitrite ( $\geq 99 \%)$ from Fluka (Honeywell International Inc., Charlotte, NC, USA), sodium sulfite ( $\geq 98.5 \%$ ) from Acros (Fisher Scientific, Hampton, NH, USA), and sulfuric acid (95\%-98\%) from Labor. The standard solutions as well as pollutant solution and eluents were prepared with ultrapure water obtained from the Direct-Q Millipore system (Merck KGaA, Darmstadt, Germany). 


\subsection{Preparation and Characterization of Catalysts}

For the evaluation of SMX degradation, by the tested catalytic processes, four catalysts were selected. CNTs (Nanocyl 3100, Nanocyl SA., Sambreville, Belgium) were used as received. $\mathrm{TiO}_{2}$ was prepared by the sol-gel method [34,35]. Briefly, the precursor titanium (IV) isopropoxide $\left(\mathrm{C}_{12} \mathrm{H}_{28} \mathrm{O}_{4} \mathrm{Ti}\right)$ was dropwise added to $125 \mathrm{~mL}$ of ethanol at room temperature under magnetic stirring, and the solution was maintained under stirring for $30 \mathrm{~min}$. Then, $1 \mathrm{~mL}$ of nitric acid was added, and the solution was stirred until gel formation. After evaporation of the solvent at room temperature, the sample was ground, and the powder obtained was thermally treated at $400{ }^{\circ} \mathrm{C}$ under nitrogen flow for $2 \mathrm{~h}$. The iron catalyst supported on carbon nanotubes (Fe/CNT) was prepared by the incipient wetness impregnation method using CNT as the support of the metal phase (Fe). For this, a solution of $324.8 \mathrm{mg} \mathrm{Fe}\left(\mathrm{NO}_{3}\right)_{3} \cdot 9 \mathrm{H}_{2} \mathrm{O}$ was added dropwise through a peristaltic pump (Ismatec ${ }^{\circledR}$, Wertheim, Germany) to $2.2 \mathrm{~g}$ of CNT in order to obtain a content of $2 \%$ of iron $(\% \mathrm{wt})$. The addition was performed under ultrasonic mixing. After impregnation, the sample was dried at $100{ }^{\circ} \mathrm{C}$ during $24 \mathrm{~h}$. Finally, the material was thermally treated under nitrogen flow (purity of $99.999 \%$ purchased from Linde Portugal, Lda., Lisboa, Portugal) of $100 \mathrm{~cm}^{3} \mathrm{~min}^{-1}$ at $400{ }^{\circ} \mathrm{C}$ for $1 \mathrm{~h}$, followed by a reduction under hydrogen (purity of $99.999 \%$ purchased from Linde Portugal, Lda.) with $100 \mathrm{~cm}^{3} \mathrm{~min}^{-1}$ flow rate during $3 \mathrm{~h}$ at $400^{\circ} \mathrm{C}$. The iron reduction temperature was determined by the temperature programmed reduction (TPR) technique. The composite $\mathrm{TiO}_{2} / \mathrm{CNT}$ was prepared in a ball milling, according to optimal conditions previously determined, during $30 \mathrm{~min}$ at 10 vibrations s$^{-1}$ in a Retsch MM 200 equipment using $90 \% \mathrm{TiO}_{2}$ and $10 \%$ of $\mathrm{CNT}$ [36].

To evaluate the chemical and textural properties, the prepared catalysts were characterized by several techniques. Thermogravimetric analyses were performed in an STA 409 PC/4/H Luxx equipment of Netzsch until $900{ }^{\circ} \mathrm{C}$ using helium as insert carrier gas and air as burning gas. Textural properties were evaluated by nitrogen adsorption isotherms at $-196{ }^{\circ} \mathrm{C}$, held in a Quantachrome NOVA 4200e apparatus. Approximately $0.1 \mathrm{~g}$ of each sample was previously submitted to a degassing program for $3 \mathrm{~h}$ at $150{ }^{\circ} \mathrm{C}$. Additionally, the catalyst Fe/CNT was analyzed by temperature programmed reduction (TPR) in an AMI-200 (Altamira Instruments, Pittsburgh, PA, USA). Fe/CNT was reduced under a gas stream of $5 \%(v / v)$ of $\mathrm{H}_{2}$ diluted in Ar until $700{ }^{\circ} \mathrm{C}$. The $\mathrm{H}_{2}$ consumption was measured by a thermal conductivity detector (TCD). The morphology of this sample was also analyzed by transmission electron microscopy (TEM) in a LEO microscope model 906E with an acceleration voltage of $120 \mathrm{kV}$. The sample was previously dispersed in ethanol in an ultrasonic bath. One drop of this suspension was deposited on a copper grid with a formvar film.

$\mathrm{TiO}_{2}$-based catalysts were also analyzed by X-ray diffraction, performed by a PANalytical X'Pert PRO diffractometer with a $\mathrm{Cu}$ Ka radiation source $(\lambda=1.54 \mathrm{~nm})$. The voltage and current used were $50 \mathrm{kV}$ and $40 \mathrm{~mA}$, respectively. The results were collected in the range of $2 \theta$ between $10^{\circ}$ and $90^{\circ}$ with a speed of $0.017^{\circ} \mathrm{s}^{-1}$. The Rietveld refinement was used to analyze the results.

\subsection{Catalytic Tests}

All SMX degradation reactions were performed in the same photochemical glass reactor $(60 \mathrm{~mm}$ diameter, $250 \mathrm{~mm}$ height). A glass reactor was chosen, since all processes studied can be performed in this kind of reactor. Therefore, it is possible to make an authentic comparison of the results. The initial SMX concentration used was $30 \mathrm{mg} \mathrm{L}^{-1}$ at natural $\mathrm{pH}(\approx 5.1)$. The initial SMX concentration selected for this study was $30 \mathrm{mg} \mathrm{L}^{-1}$, to allow easier comparison between the different treatments and to study the mineralization degree by total organic carbon (TOC) measurements. The experiments were carried out at the natural $\mathrm{pH}$ of the initial solution $(\approx 5.1)$, avoiding adding additional chemicals for $\mathrm{pH}$ control. The $\mathrm{pH}$ and concentration used in this work were selected to clearly distinguish the different processes at the natural $\mathrm{pH}$ of the solution. If the experiments were carried out at lower concentrations, in the range of $\mathrm{n} \mathrm{L}^{-1}$, the comparison between the different processes would not be accurate, especially in terms of mineralization degree. The reactor has $250 \mathrm{~mL}$ capacity, and the reactions were performed under a constant agitation of $400 \mathrm{rpm}$. 
In photoreactions, a Heraeus TQ150 medium pressure mercury vapor lamp was used as an irradiation source, delivering near-UV/Vis irradiation $\left(\lambda>350 \mathrm{~nm} ; 50 \mathrm{~mW} \mathrm{~cm}^{-2}\right)$. A recirculation glass jacket (Duran ${ }^{\circledR} 50$, Mainz, Germany) placed around the lamp, with the main resulting emission lines at $\lambda_{\text {exc }}=365,405,436,546$, and $578 \mathrm{~nm}$. A UV-vis spectroradiometer (USB2000+, Ocean Optics, Winter Park, FL, USA) was used to measure the light intensity and photon flux. The obtained values of UV dose and photon flux were $4.6 \times 105 \mathrm{~mJ} \mathrm{~cm}^{-2}$ and $9.7 \times 1016$ photons $\mathrm{cm}^{-2} \mathrm{~s}^{-1}$, respectively.

In all catalytic reactions, $125 \mathrm{mg}$ of catalyst (optimal amount) was added. The collected samples were centrifuged for $15 \mathrm{~min}$ at $13.5 \mathrm{rpm}$ using a VWR MicroStar 12 centrifuge to ensure the absence of suspended particles during analytic analysis.

Ozone $\left(\mathrm{O}_{3}\right)$ was generated from pure oxygen through a BMT 802X generator, and its concentration was monitored by a BMT 960 analyzer (BMT MESSTECHNIK GMBH, Stahnsdorf, Germany). The $\mathrm{O}_{3}$ flow rate and concentration used were of $150 \mathrm{~cm}^{3} \mathrm{~min}^{-1}$ and $50 \mathrm{~g} \mathrm{~m}^{-3}$, respectively. The gas stream charging was carried out through a diffuser with $1 \mathrm{~cm}$ of diameter, and the $\mathrm{O}_{3}$ gas, which had left the reactor, passed by washing bottles with potassium iodide (KI 20\%). In all reactions where $\mathrm{O}_{3}$ was not involved, $\mathrm{O}_{2}$ was used to keep the same experimental conditions.

In $\mathrm{H}_{2} \mathrm{O}_{2}$-based reactions, a theoretical stoichiometric amount of $\mathrm{H}_{2} \mathrm{O}_{2}$ was added, determined by Equation (1), considering an excess of $50 \%(45.3 \mu \mathrm{L})$. Sodium sulfite $\left(\mathrm{Na}_{2} \mathrm{SO}_{3}\right)$ was added to the samples collected in these reactions to ensure complete consumption of $\mathrm{H}_{2} \mathrm{O}_{2}$ and stop the reaction, according to Equation (2).

$$
\begin{gathered}
\mathrm{C}_{10} \mathrm{H}_{11} \mathrm{~N}_{3} \mathrm{O}_{3} \mathrm{~S}+33 \mathrm{H}_{2} \mathrm{O}_{2} \rightarrow 10 \mathrm{CO}_{2}+36 \mathrm{H}_{2} \mathrm{O}+\mathrm{H}_{2} \mathrm{SO}_{4}+3 \mathrm{HNO}_{3} \\
\mathrm{Na}_{2} \mathrm{SO}_{3}+\mathrm{H}_{2} \mathrm{O}_{2} \rightarrow \mathrm{Na}_{2} \mathrm{SO}_{4}+\mathrm{H}_{2} \mathrm{O}
\end{gathered}
$$

All individual processes were tested, in the presence and absence of catalysts, as well as all possible combinations of the three tested processes $\left(\mathrm{O}_{3}\right.$, light, and $\left.\mathrm{H}_{2} \mathrm{O}_{2}\right)$. The detailed information of non-catalytic runs with individual and combined processes was previously published [33].

\subsection{Analytic Methods}

SMX and primary degradation products, AMI and BZQ, as shown in Table 1, were detected by high-performance liquid chromatography (HPLC) with a Hitachi Elite LaChrom equipment with diode detector (DAD). The stationary phase was composed by LiChroCART Purospher STAR RP-18 (Merck Millipore, Burlington, MA, USA) column $(250 \times 4.6 \mathrm{~mm})$, and the mobile phase was a gradient of water and methanol with a flow rate of $1 \mathrm{~mL} \mathrm{~min}^{-1}$ and an injection volume of $50 \mu \mathrm{L}$. The wavelengths used for SMX, AMI, and BZQ were 265, 210, and $225 \mathrm{~nm}$, respectively.

The determination of final by-products of SMX degradation, OXM and OXL, as shown in Table 1, was performed by HPLC Hitachi Elite LaChrom (Hitachi High-Technologies Corporation, Kagoshima, Japan) equipped with a UV detector, using an Alltech AO-1000 (Fisher Scientific, Hampton, NH, USA) column $(300 \times 6.5 \mathrm{~mm})$ and a mobile phase composed by $5 \mathrm{mM} \mathrm{H}_{2} \mathrm{SO}_{4}$ solution at a flow rate of

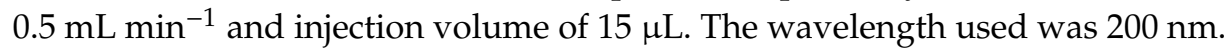

Ion chromatography was used to analyze the formation of ion species $\left(\mathrm{SO}_{4}{ }^{2-}, \mathrm{NO}_{3}{ }^{-}\right.$, and $\left.\mathrm{NH}_{4}{ }^{+}\right)$ that may be released during SMX degradation. This analysis was performed on a Metrohm 881 Compact IC Pro equipment. The $\mathrm{SO}_{4}{ }^{2-}$ and $\mathrm{NO}_{3}{ }^{-}$ions were detected in the Metrosep A Supp 7 column $(250 \times 4 \mathrm{~mm})$ with a Metrosep P2 Guard/3.5 pre-column. The mobile phase was composed by a solution of $3.6 \mathrm{mM} \mathrm{Na}_{2} \mathrm{CO}_{3}$, flow rate of $0.7 \mathrm{~mL} \mathrm{~min}^{-1}$, and injection volume of $20 \mu \mathrm{L}$. The analysis was performed at $45^{\circ} \mathrm{C}$. A Metrosep C4 column $(250 \times 4.0 \mathrm{~mm})$ from Metrohm with Metrosep C4-S-Guard/4.0 pre-column was used for $\mathrm{NH}_{4}{ }^{+}$determination. The eluent was a solution of $0.7 \mathrm{mM}$ of 2,6-pyridine dicarboxylic acid and a solution of $1.7 \mathrm{mM}$ of nitric acid at $0.7 \mathrm{~mL} \mathrm{~min}^{-1}$ flow rate. The analysis was performed at $25^{\circ} \mathrm{C}$ and with an injection volume of $20 \mu \mathrm{L}$.

The determination of total organic carbon (TOC) was performed in a L-TOC Total Organic Carbon Analyzer of Shimadzu coupled to an ASI-L auto sampler of the same brand, by the Non-Purgable 
Organic Carbon (NPOC) method. The collected samples, already centrifuged, were analyzed without any previous preparation.

The toxicity of treated samples was evaluated by the Microtox ${ }^{\circledR}$ (Guildford, UK) acute toxicity test according to the procedure established by standard methods (ISO/DIS 11348-3) [37].

Table 1. Characteristics of sulfamethoxazole (SMX) and intermediate compounds mentioned in this work.

\begin{tabular}{|c|c|c|c|c|c|}
\hline Compound & Structure & Formula & $\begin{array}{c}\mathrm{M} \\
\left(\mathrm{g} \mathrm{mol}^{-1}\right)\end{array}$ & $\begin{array}{l}\mathrm{LOD}^{*} \\
\left(\mathrm{mg} \mathrm{L}^{-1}\right)\end{array}$ & $\mathbf{r}^{2}$ \\
\hline SMX & & $\mathrm{C}_{10} \mathrm{H}_{11} \mathrm{~N}_{3} \mathrm{O}_{3} \mathrm{~S}$ & 253.28 & 0.08 & 0.99989 \\
\hline AMI & & $\mathrm{C}_{4} \mathrm{H}_{6} \mathrm{~N}_{2} \mathrm{O}$ & 98.1 & 0.05 & 0.99998 \\
\hline BZQ & & $\mathrm{C}_{6} \mathrm{H}_{4} \mathrm{O}_{2}$ & 108.09 & 0.1 & 0.99984 \\
\hline OXM & & $\mathrm{C}_{2} \mathrm{H}_{3} \mathrm{NO}_{3}$ & 89.05 & 0.05 & 0.9995 \\
\hline OXL & & $\mathrm{C}_{2} \mathrm{H}_{2} \mathrm{O}_{4}$ & 90.03 & 0.5 & 0.99940 \\
\hline
\end{tabular}

${ }^{*}$ LOD-Limit of detection.

\section{Results}

\subsection{Catalyst Characterization}

The textural properties of the catalysts are presented in Table 2. The highest surface areas $\left(\mathrm{S}_{\mathrm{BET}}\right)$ were verified in $\mathrm{CNT}$ and $\mathrm{Fe} / \mathrm{CNT}$ samples, but Fe/CNT has a slightly lower area due to iron impregnated on the surface of the CNT. On the other hand, $\mathrm{TiO}_{2}$ has the lowest surface area and pore volume.

Table 2. Textural properties of the prepared catalysts and crystal properties of $\mathrm{TiO}_{2}$ and $\mathrm{TiO}_{2} /$ carbon nanotube (CNT) samples.

\begin{tabular}{|c|c|c|c|c|}
\hline Sample & $\begin{array}{l}S_{\text {BET }}\left(\mathrm{m}^{2} \mathrm{~g}^{-1}\right) \\
\left( \pm 10 \mathrm{~m}^{2} \mathrm{~g}^{-1}\right)\end{array}$ & $\begin{array}{c}V_{P(P / P o=0.95)}\left(\mathrm{cm}^{3} \mathrm{~g}^{-1}\right) \\
\quad\left( \pm 0.005 \mathrm{~cm}^{3} \mathrm{~g}^{-1}\right)\end{array}$ & \% Crystal Phase & $\begin{array}{c}\text { Crystal Diameter } \\
(\mathrm{nm})\end{array}$ \\
\hline CNT & 262 & 0.556 & - & - \\
\hline $\mathrm{Fe} / \mathrm{CNT}$ & 252 & 0.689 & - & - \\
\hline $\mathrm{TiO}_{2}$ & 134 & 0.112 & $\begin{array}{c}\text { Anatase } 93 \% \\
\text { Rutile } 7 \%\end{array}$ & $\begin{array}{c}\text { Anatase } 8.91 \\
\text { Rutile } 14.7\end{array}$ \\
\hline $\mathrm{TiO}_{2} / \mathrm{CNT}$ & 142 & 0.164 & $\begin{array}{c}\text { Anatase } 97 \% \\
\text { Rutile 3\% }\end{array}$ & $\begin{array}{c}\text { Anatase } 14.6 \\
\text { Rutile } 40.7\end{array}$ \\
\hline
\end{tabular}

The results of the XRD analysis for $\mathrm{TiO}_{2}$ and $\mathrm{TiO}_{2} / C N T$ are also shown in Table 2. The crystalline phases were identified by applying the Rietveld refinement. The crystal composition of $\mathrm{TiO}_{2}$ is $93 \%$ of anatase and $7 \%$ of rutile, while $\mathrm{TiO}_{2} / \mathrm{CNT}$ contains $97 \%$ of anatase and $3 \%$ of rutile. The difference in 
crystal percentage between $\mathrm{TiO}_{2}$ and $\mathrm{TiO}_{2} / \mathrm{CNT}$ probably occurs because of the method used in the mixing of catalysts, which can modify the $\mathrm{TiO}_{2}$ crystal phase. The results show that the $\mathrm{TiO}_{2}$-based catalysts are formed by a higher percentage of anatase form which corresponds to the most active crystal for photocatalytic reactions.

As expected, TGA analysis (results not shown) demonstrates that CNT and Fe/CNT have a higher mass loss due to the burning of carbon material during heating; furthermore, $\mathrm{Fe} / \mathrm{CNT}$ has a lower mass loss due to the presence of iron. $\mathrm{TiO}_{2}$ presents little mass loss, as expected since $\mathrm{TiO}_{2}$ is thermodynamically stable and formed mainly by rutile and anatase crystals. The determined fractions of $\mathrm{CNT}$ and $\mathrm{TiO}_{2}$ in the composite are $15 \%$ and $85 \%$, respectively.

TPR analysis of $\mathrm{Fe} / \mathrm{CNT}$ under $5 \%$ of hydrogen flow determined the temperature of reduction of the metal. Two reduction peaks were observed-a first peak between 300 and $400{ }^{\circ} \mathrm{C}$, where the metal is reduced to $\mathrm{Fe}_{3} \mathrm{O}_{4}$, and a second peak between 400 and $600{ }^{\circ} \mathrm{C}$, which corresponds to a sequential reduction of $\mathrm{Fe}_{3} \mathrm{O}_{4}$ to $\mathrm{FeO}$ and $\mathrm{Fe}^{0}$ [6]. TEM analysis, as shown in Figure 1, shows the presence of impregnated iron in the catalyst with uniform particle size and uniform metal distribution on the surface of the CNT.

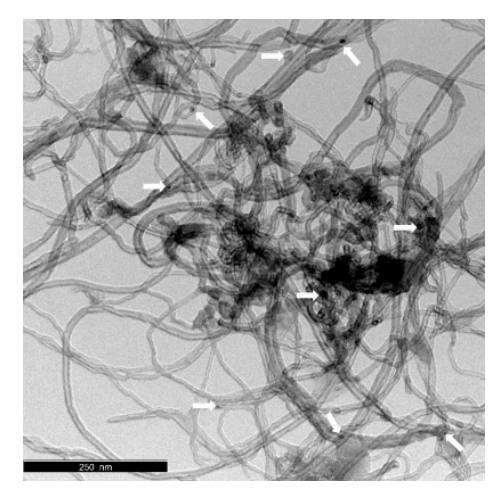

Figure 1. TEM image from the Fe/CNT catalyst.

\subsection{SMX and TOC Removal}

SMX and TOC removals achieved during catalytic ozonation, photocatalysis, and photocatalytic ozonation are presented in Figure 2.

In ozonation catalyzed by $\mathrm{CNT}$ and $\mathrm{Fe} / \mathrm{CNT}$, SMX was removed faster in the early stages; however, after 10 min of reaction, SMX present in solution was removed entirely in all ozonation systems. Regarding the TOC removal, ozonation catalyzed by $\mathrm{TiO}_{2}$ promotes a removal of $41 \%$, which is lower than the amount obtained by single ozonation; $\mathrm{TiO}_{2}$ is a photoactive catalyst and poorly reacts in the presence of $\mathrm{O}_{3}$. The catalytic ozonation in the presence of $\mathrm{Fe} / \mathrm{CNT}$ led to the highest mineralization level; $75 \%$ of removal after $3 \mathrm{~h}$ of reaction.

Iron, like other transition metals, shows significant catalytic activity in ozonation, once it promotes the decomposition of dissolved $\mathrm{O}_{3}$ in hydroxyl radicals, especially in acidic conditions, as shown in Equation (3). In this case, the presence of CNT avoids hydrolysis and iron precipitation, while iron promotes the increase of the number of active centers on the catalyst surface; thus, the formation of $\mathrm{OH}^{\bullet}$ radicals increases and, consequently, the oxidation of intermediates formed during the reaction is promoted, leading to a higher mineralization $[38,39]$. Additionally, $\mathrm{O}_{3}$ adsorption and reactions on the surface of the CNT can occur, and generation of surface oxygen radicals is promoted, justifying the importance of the textural properties in these processes $[3,5,26]$.

$$
\mathrm{Fe}^{3+}+\mathrm{O}_{3}+\mathrm{H}_{2} \mathrm{O} \rightarrow \mathrm{FeO}^{2+}+\mathrm{OH}^{\bullet}+\mathrm{O}_{2}+\mathrm{H}^{+}
$$

Photocatalysis in the presence of CNT and Fe/CNT ensured higher SMX removal in the early stages, but after $120 \mathrm{~min}$ of reaction no differences were observed and SMX present in solution, as 
shown in Figure 2c, was degraded in all systems. On the other hand, a catalyst is required to achieve exceptional levels of mineralization, as can be seen in Figure 2d. The Fe/CNT led to the highest TOC removal reaching mineralization of $78 \%$, while only $14 \%$ is removed by the non-catalytic process. The combination of $\mathrm{CNT}$ and $\mathrm{TiO}_{2}$ increases the catalytic activity in terms of TOC removal, probably due to the formation of more oxidizing radicals. CNT material is a photosensitizer, has a reducer character, and high electronic conductivity; thus, it can increase the mobility of electrons and hence the formation of radicals is improved, increasing the degradation, especially of the intermediaries, and consequently more significant mineralization was attained.

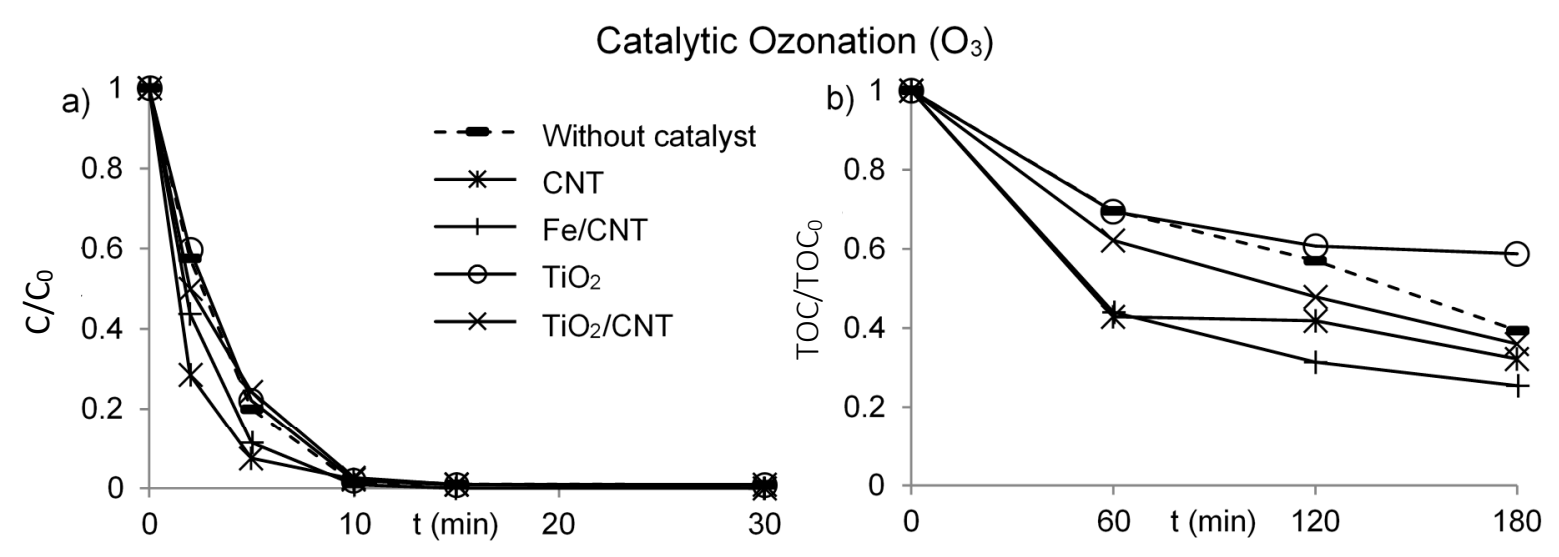

Photocatalysis $(\mathrm{L})$
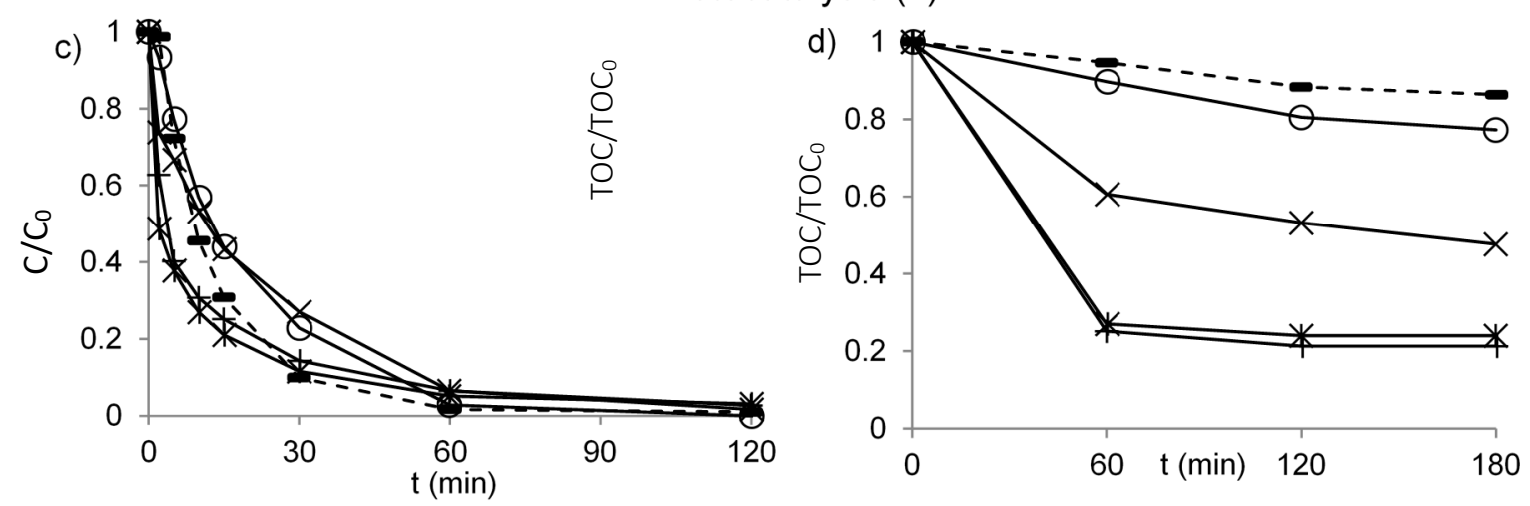

Photocatalitic Ozonation $\left(\mathrm{L} / \mathrm{O}_{3}\right)$
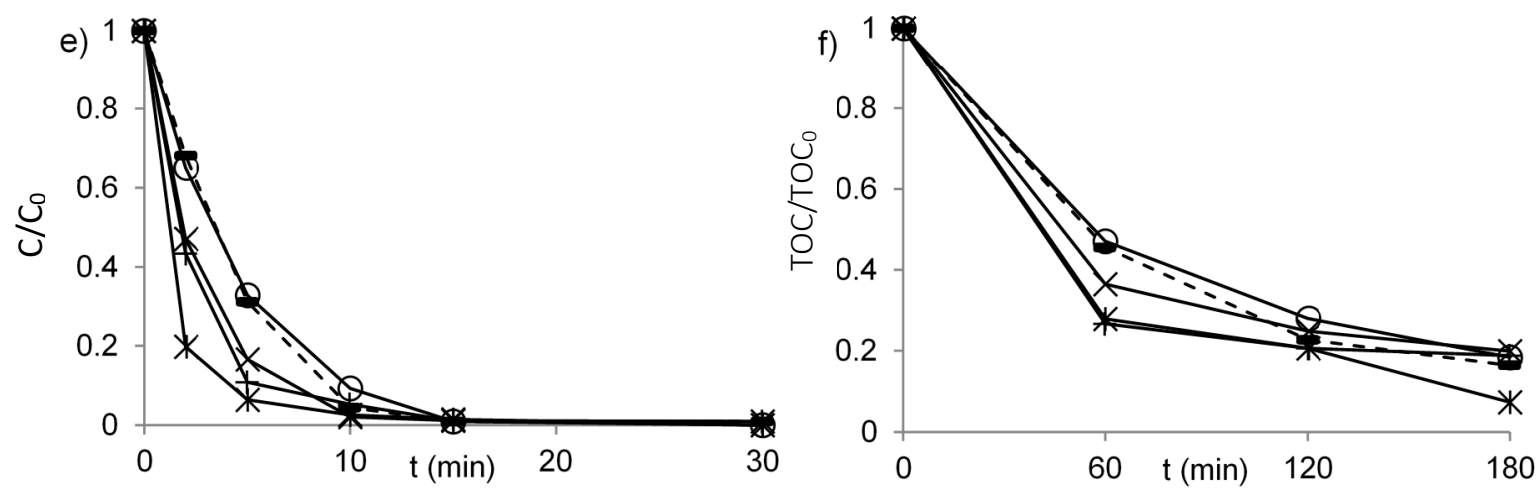

Figure 2. Dimensionless SMX (a,c,e) and total organic carbon (TOC) $(\mathbf{b}, \mathbf{d}, \mathbf{f})$ concentration during catalytic ozonation $\left(\mathrm{O}_{3}\right)$, photocatalysis $(\mathrm{L})$, and photocatalytic ozonation $\left(\mathrm{L} / \mathrm{O}_{3}\right)$ in the presence of $\mathrm{CNT}, \mathrm{Fe} / \mathrm{CNT}, \mathrm{TiO}_{2}$, and $\mathrm{TiO}_{2} / \mathrm{CNT}$.

The results of SMX removal by catalytic oxidation with $\mathrm{H}_{2} \mathrm{O}_{2}$ are depicted in Figure 3, together with the adsorption results on $\mathrm{TiO}_{2}$ and CNT. 

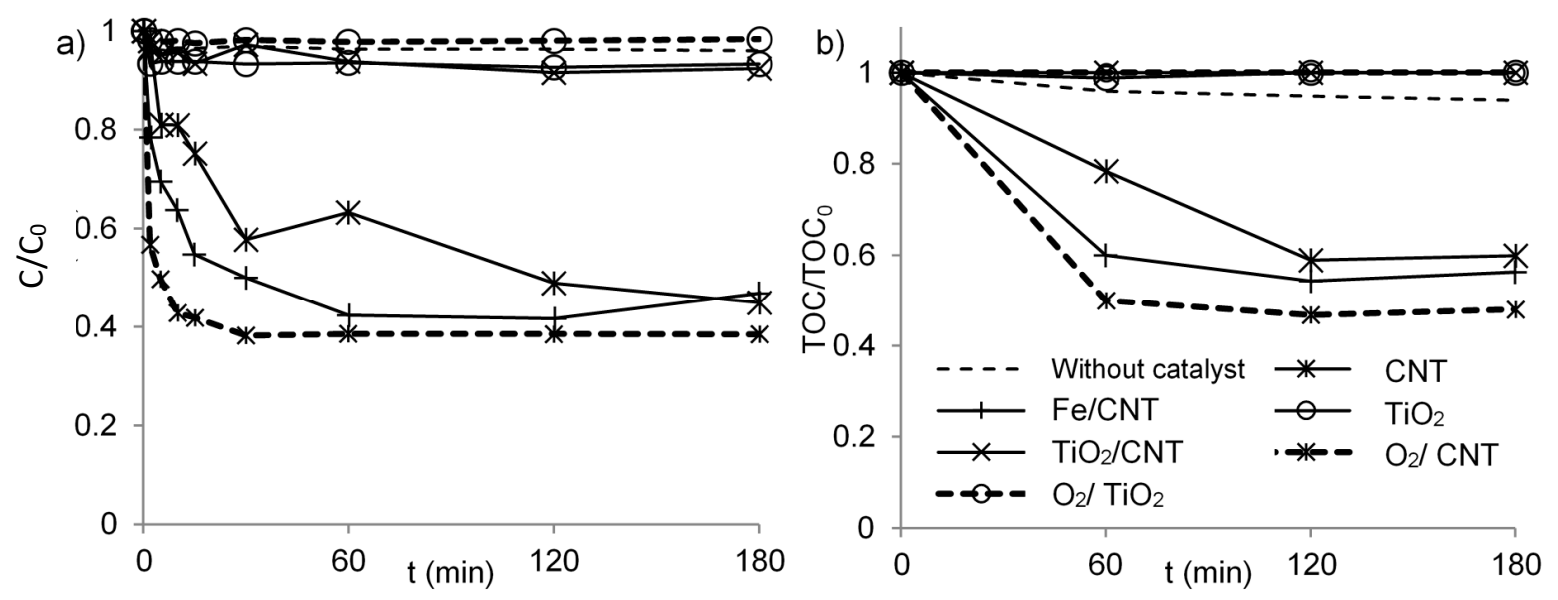

Figure 3. Dimensionless SMX (a) and TOC (b) concentration during $\mathrm{H}_{2} \mathrm{O}_{2}$ catalytic oxidation and adsorption experiments $\left(\mathrm{O}_{2}\right)$ on $\mathrm{CNT}$, $\mathrm{Fe} / \mathrm{CNT}$, $\mathrm{TiO}_{2}$, and $\mathrm{TiO}_{2} / \mathrm{CNT}$.

SMX adsorption was not observed on $\mathrm{TiO}_{2}$, which was expected since $\mathrm{TiO}_{2}$ is highly stable and it has a small surface area and pore volume. Abellán et al. [40], Baran et al. [41], and Su et al. [42] reported similar adsorption results to those obtained in this work. Moreover, adsorption on CNT removed $61 \%$ of SMX and reached a TOC removal of $52 \%$ after $3 \mathrm{~h}$. The adsorption of SMX is more pronounced in the early stages of the contact time, remaining constant after the initial stage due to surface saturation. The high surface area and volume of pores of the CNT may justify the high adsorption values. Gonçalves et al. $[5,26]$ presented a similar profile; however, the adsorption degree obtained was lower (between $30 \%$ and $50 \%)$, probably due to the lower catalyst concentration $\left(0.143 \mathrm{~g} \mathrm{~L}^{-1}\right)$ used.

SMX was not entirely removed by catalytic oxidation with $\mathrm{H}_{2} \mathrm{O}_{2}$, and its concentration remained constant during the $3 \mathrm{~h}$ of reaction in the presence of $\mathrm{TiO}_{2}$ and $\mathrm{TiO}_{2} / \mathrm{CNT}$ catalysts. The highest removals were achieved by the addition of $\mathrm{CNT}$ and $\mathrm{Fe} / \mathrm{CNT}$, removing approximately $50 \%$ of SMX after $3 \mathrm{~h}$ of reaction. Intermediates and ions were not detected in any reaction with $\mathrm{H}_{2} \mathrm{O}_{2}$. The reduction profile of SMX concentration and TOC verified in the oxidation of $\mathrm{H}_{2} \mathrm{O}_{2}$ with CNT and $\mathrm{Fe} / \mathrm{CNT}$ was similar to adsorption on the CNT profile. Considering this similarity and the absence of intermediates in solution, it is possible that SMX removal, in this case, occurred due to adsorption and not by oxidation. However, when CNTs were combined with $\mathrm{H}_{2} \mathrm{O}_{2}$, less removal was observed, probably due to competition between $\mathrm{H}_{2} \mathrm{O}_{2}$ and SMX for the CNT active centers, reducing, therefore, the adsorption capacity of the catalyst $[4,26,43]$.

In photocatalytic ozonation, as shown in Figure 2e,f, an improvement in the degradation of SMX was verified when compared to the non-catalytic process, except in the presence of $\mathrm{TiO}_{2}$. The presence of $\mathrm{CNT}, \mathrm{Fe} / \mathrm{CNT}$, and $\mathrm{TiO}_{2} / \mathrm{CNT}$ accelerated SMX degradation; however, after $15 \mathrm{~min}$ of reaction, SMX was completely degraded by all tested systems. The TOC removal results show that the highest mineralization occurred in the presence of CNT (93\%), while the remaining reactions allowed $84 \%$ of TOC removal at the end of the reaction.

Comparing the SMX degradation by photocatalytic ozonation with correspondent individual processes, photocatalysis, and catalytic ozonation, it is possible to observe that in the combined process carried out with CNT, SMX was degraded faster and higher mineralization was reached. This result demonstrates that the combination of radiation, $\mathrm{O}_{3}$, and catalyst is beneficial for SMX degradation.

The catalytic ozonation with $\mathrm{H}_{2} \mathrm{O}_{2}$ was insensitive to the used catalyst, as shown in Figure 4. In the case of TOC removal, a fast mineralization rate was observed when $\mathrm{Fe} / \mathrm{CNT}$ and $\mathrm{TiO}_{2} / \mathrm{CNT}$ were added, removing approximately $75 \%$ of the organic matter after $3 \mathrm{~h}$ of reaction. Moreover, catalytic ozonation with $\mathrm{H}_{2} \mathrm{O}_{2}$ and $\mathrm{TiO}_{2}$ presented higher TOC in solution than the non-catalytic process, probably because $\mathrm{TiO}_{2}$ is not an ozonation catalyst. 


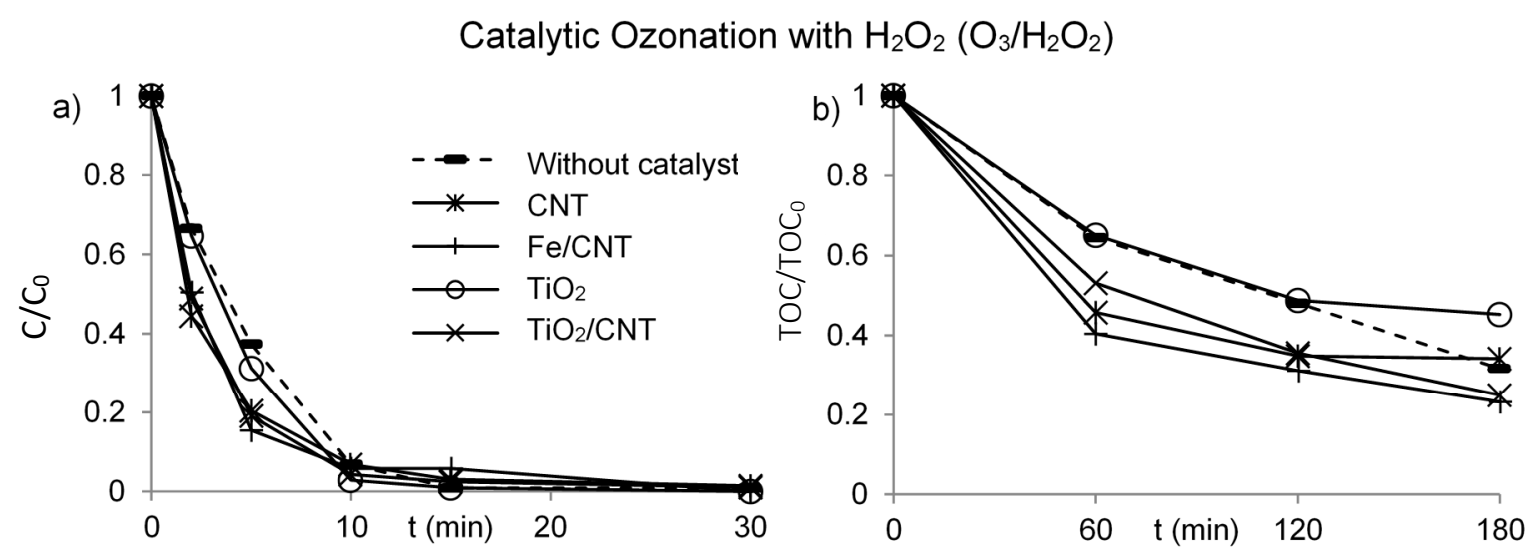

Photocatalysis with $\mathrm{H}_{2} \mathrm{O}_{2}\left(\mathrm{~L} / \mathrm{H}_{2} \mathrm{O}_{2}\right)$
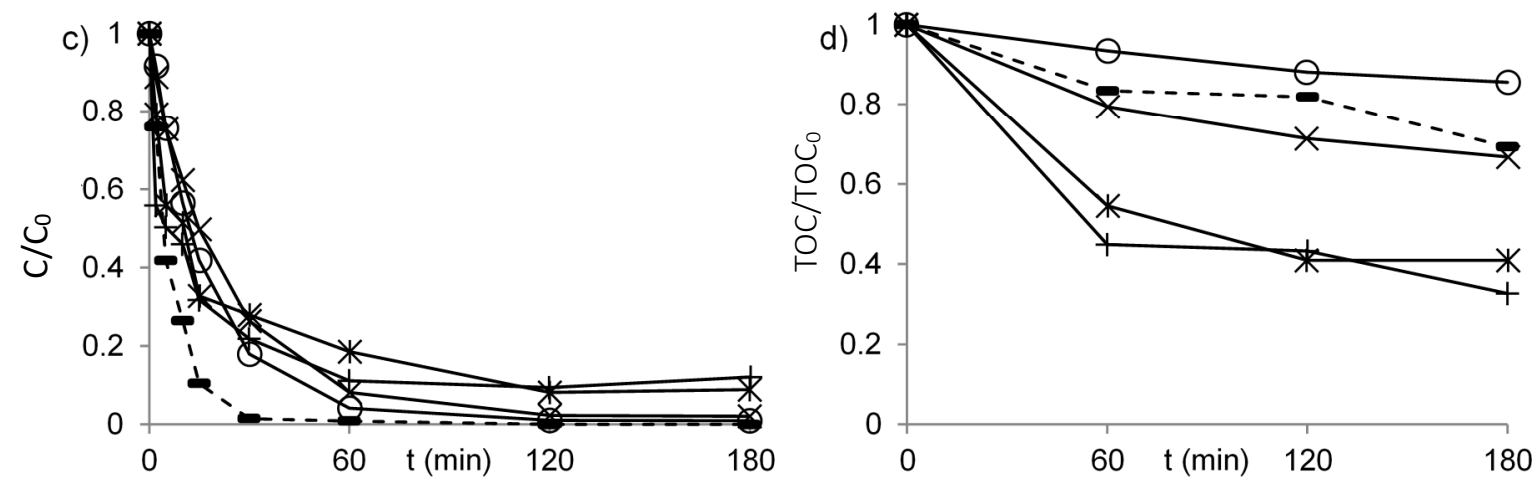

Figure 4. Dimensionless $\operatorname{SMX}(\mathbf{a}, \mathbf{c})$ and TOC $(\mathbf{b}, \mathbf{d})$ concentration during catalytic ozonation with $\mathrm{H}_{2} \mathrm{O}_{2}\left(\mathrm{O}_{3} / \mathrm{H}_{2} \mathrm{O}_{2}\right)$ and photocatalysis with $\mathrm{H}_{2} \mathrm{O}_{2}\left(\mathrm{~L} / \mathrm{H}_{2} \mathrm{O}_{2}\right)$ in the presence of $\mathrm{CNT}, \mathrm{Fe} / \mathrm{CNT}$, $\mathrm{TiO}$, and $\mathrm{TiO}_{2} / \mathrm{CNT}$.

The mineralization of the SMX was not increased during catalytic ozonation and catalytic ozonation with $\mathrm{H}_{2} \mathrm{O}_{2}$ in the presence of $\mathrm{Fe} / \mathrm{CNT}$ catalyst, indicating that the addition of $\mathrm{H}_{2} \mathrm{O}_{2}$ to ozonation is not advantageous under the operating conditions used. As previously mentioned, the $\mathrm{H}_{2} \mathrm{O}_{2}$ added can adsorb on the catalyst surface and change its surface, reducing the available active centers and therefore decreasing the reaction as well as the formation of superficial radicals [5]. Furthermore, the amount of $\mathrm{H}_{2} \mathrm{O}_{2}$ added to the system may not be enough, so it would be necessary to optimize the $\mathrm{H}_{2} \mathrm{O}_{2}$ concentration and the $\mathrm{pH}$ of the solution to improve the results.

The presence of $\mathrm{H}_{2} \mathrm{O}_{2}$ in the photocatalytic reactions did not improve the SMX removal rates, as shown in Figure 4. However, except for the system with $\mathrm{TiO}_{2}$, most of the catalytic systems had better performance in TOC removal than non-catalytic combinations. Although some studies show that the addition of $\mathrm{H}_{2} \mathrm{O}_{2}$ to the photocatalysis with $\mathrm{TiO}_{2}$ improves the process, this was not observed in this work probably due to the use of non-optimized $\mathrm{H}_{2} \mathrm{O}_{2}$ concentration and $\mathrm{pH}[14,39]$. $\mathrm{TiO}_{2}$ can decompose $\mathrm{H}_{2} \mathrm{O}_{2}$ into radicals different than $\mathrm{OH}^{\bullet}$, promoting other reaction mechanisms and consequently the formation of other intermediates, unidentified in this work, which are less efficient.

Comparing the TOC results of photocatalysis and photocatalysis with $\mathrm{H}_{2} \mathrm{O}_{2}, \mathrm{CNT}$ and $\mathrm{Fe} / \mathrm{CNT}$ samples had the highest removal of organic matter in both cases, but in the combined method $\left(\mathrm{L} / \mathrm{H}_{2} \mathrm{O}_{2}\right)$ the mineralization rates were lower. The reduction in the mineralization rate can be explained by the competition between $\mathrm{H}_{2} \mathrm{O}_{2}$ and SMX for the active centers of catalysts, as mentioned before, since $\mathrm{H}_{2} \mathrm{O}_{2}$ may be adsorbed on the active centers of the catalyst and they become unavailable for the reaction, which decreases surface reactions. 
The results of photocatalytic ozonation with $\mathrm{H}_{2} \mathrm{O}_{2}$ presented in Figure 5 allowed the conclusion that the addition of catalysts, especially the composite $\mathrm{TiO}_{2} / \mathrm{CNT}$, slightly increases the SMX degradation rate, but after $30 \mathrm{~min}$ no differences among the tested reactions were observed. Regarding the TOC removal, $\mathrm{CNT}$ and $\mathrm{Fe} / \mathrm{CNT}$ had better efficiency than the non-catalytic process, and total mineralization of the solution was attained in the presence of the Fe/CNT catalyst.
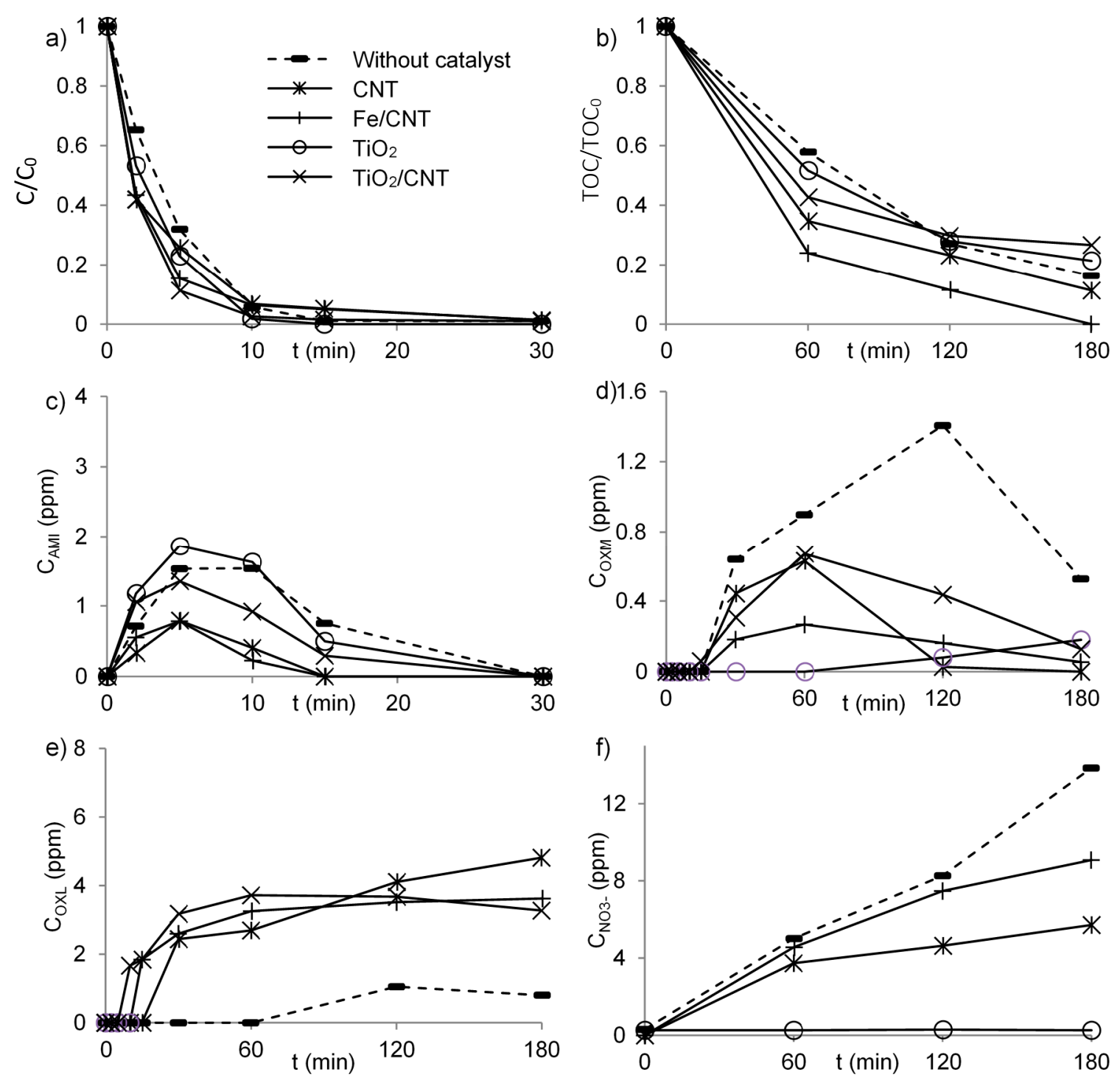

Figure 5. Dimensionless concentration of SMX (a) and TOC (b) and evolution of AMI (c), OXM (d), OXL (e), and $\mathrm{NO}_{3}{ }^{-}$(f) concentrations during photocatalytic ozonation with $\mathrm{H}_{2} \mathrm{O}_{2}$ in the presence of $\mathrm{CNT}, \mathrm{Fe} / \mathrm{CNT}, \mathrm{TiO}_{2}$, and $\mathrm{TiO}_{2} / \mathrm{CNT}$.

Analyzing the results of photocatalytic ozonation and photocatalytic ozonation with $\mathrm{H}_{2} \mathrm{O}_{2}$, it is possible to observe that the addition of $\mathrm{H}_{2} \mathrm{O}_{2}$ improves the mineralization degree and $\mathrm{L} / \mathrm{O}_{3} / \mathrm{H}_{2} \mathrm{O}_{2}$ in the presence of $\mathrm{CNT}$ and $\mathrm{Fe} / \mathrm{CNT}$ achieved a better mineralization level, possibly due to the formation of higher amounts of oxidizing radicals. $\mathrm{H}_{2} \mathrm{O}_{2}$ can be decomposed in the presence of Fe or light and/or participate in the formation of other radicals with $\mathrm{O}_{3}$, as described in Equation (4) [44], Equation (5) [45], and Equation (6) [46], respectively. Furthermore, in the Fe/CNT sample, the presence of iron increases 
the available active centers in the $\mathrm{CNT}$, which favors the decomposition of $\mathrm{O}_{3}$ in radicals and the reactions on the CNT surface.

$$
\begin{gathered}
\mathrm{Fe}^{2+}+\mathrm{H}_{2} \mathrm{O}_{2} \rightarrow \mathrm{Fe}^{3+}+\mathrm{HO}^{-}+\mathrm{HO}^{\bullet} \\
\mathrm{H}_{2} \mathrm{O}_{2}+\mathrm{h} v \rightarrow 2 \mathrm{HO}^{\bullet} \\
\mathrm{H}_{2} \mathrm{O}_{2}+2 \mathrm{O}_{3} \rightarrow 2 \mathrm{HO}^{\bullet}+3 \mathrm{O}_{2}
\end{gathered}
$$

\subsection{By-Products and Intermediates Analysis}

AMI is one of the first products of SMX degradation. In $\mathrm{O}_{3}$-based processes, the detection of AMI occurs during the first $30 \mathrm{~min}$ of reaction and, in most cases, AMI concentration is lower in the presence of CNT and Fe/CNT. However, in photocatalysis and photocatalysis with $\mathrm{H}_{2} \mathrm{O}_{2}$, AMI was not degraded after 180 min of reaction (results not shown).

BZQ was detected in most of the reactions, but in concentrations lower than the quantification limit $\left(0.10 \mathrm{mg} \mathrm{L}^{-1}\right)$; thus, it was not possible to determine the amount of BZQ released. Nevertheless, BZQ was quantified in photocatalysis in the presence of CNT and Fe/CNT, probably due to the low degradation kinetics which leads to a high BZQ concentration in solution. BZQ concentration was lower in photocatalysis than in photolysis, showing that the presence of catalysts led to a lower accumulation of this intermediary in solution (results not shown).

Carboxylic acids formed are hard to degrade and usually remain in solution because they are recalcitrant compounds [16,47]. The degradation of many pollutants by the different AOPs resulted in the presence of carboxylic acids. Maleic, fumaric, succinic, glyoxylic, oxalic, and formic acids were identified as end products of the oxidation of phenol in aqueous media by the electro-Fenton process [48]. Maleic, glyoxylic, succinic, and fumaric acids were the predominant carboxylic acids formed in the earlier stages of the treatment. Glyoxylic and succinic acids started to build in the first minutes, reaching a maximum concentration at $2 \mathrm{~h}$. Glyoxylic and succinic acids disappeared, followed by the appearance of formic and oxalic acids as end products before total mineralization. During the degradation of salicylic acid by different electrochemical advanced oxidation processes, the formation of several intermediates was verified, including short-chain carboxylic acids [49]. In this study, it was suggested that $\alpha$-ketoglutaric and glycolic acids are formed by a different pathway of malic, maleic, fumaric, and tartronic acids. Glycolic acid further transformed into glyoxylic acid. All these acids independently oxidized to oxalic acid as the ultimate by-product, which directly mineralized to $\mathrm{CO}_{2}$. The degradation of beta-blockers by electro-Fenton and solar photoelectro-Fenton treatments also confirmed the destruction of aromatic intermediates by hydroxyl radicals and, consequently, the formation of carboxylic acids [50]. The presence of oxalic and oxamic acids as end by-products was confirmed, contributing to the TOC in the treated final solution.

In most of the reactions, the concentration of carboxylic acids was lower in the presence of a catalyst than in the non-catalytic processes. For instance, in photocatalytic ozonation with $\mathrm{H}_{2} \mathrm{O}_{2}$, as shown in Figure 5d, the formation of OXM was always lower in the presence of any one catalyst than in the non-catalytic process, and in the presence of Fe/CNT and CNT, a total removal was observed. On the other hand, OXL concentration was higher in catalytic processes, probably due to the reaction mechanism which favored the formation of OXL during the degradation of SMX and primary intermediates.

The identification and quantification of $\mathrm{SO}_{4}{ }^{2-}$ and $\mathrm{NH}_{4}{ }^{+}$ions were carried out in the processes without $\mathrm{H}_{2} \mathrm{O}_{2}$ due to the interference of $\mathrm{Na}_{2} \mathrm{SO}_{3}$ in the detection method. Ion concentrations increased along time; however, in most cases, their concentration in the non-catalytic processes was higher than in the catalytic treatments. Probably, it occurred due to adsorption of ionic species on the catalyst surface or, in the case of $\mathrm{N}$-based ions, gas phase transfer could occur and ions transformed into $\mathrm{N}_{2}$ or $\mathrm{NH}_{3}$ forms (results not shown) [51]. 
In the cases where a small final concentration of detected intermediates and large amounts of organic matter $\left(\mathrm{TOC} / \mathrm{TOC}_{0}\right.$ ) were verified, it is supposed that a different reaction mechanism occurs, leading to the formation of other reaction products not identified in this work and, consequently, not quantified, but that contribute to the TOC amount.

\subsection{Replicated and Cyclic Experiments}

Duplicate tests and cyclic experiments were performed for the photocatalytic ozonation process, and the results are shown in Figures 6 and 7, respectively.

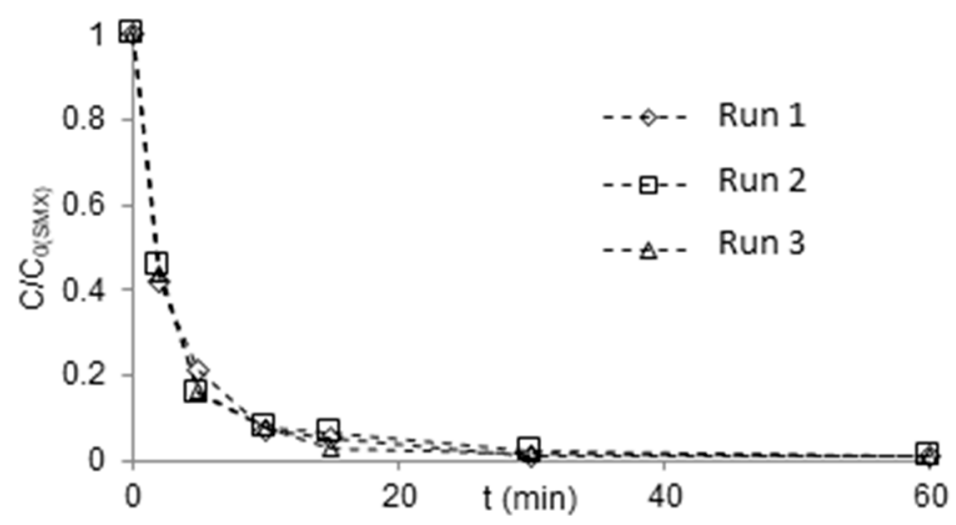

Figure 6. Dimensionless SMX concentration during reproducibility runs of photocatalytic ozonation with $\mathrm{H}_{2} \mathrm{O}_{2}\left(\mathrm{~L} / \mathrm{O}_{3} / \mathrm{H}_{2} \mathrm{O}_{2}\right)$ in the presence of $\mathrm{CNT}$.

Three repetitions of photocatalytic ozonation with $\mathrm{H}_{2} \mathrm{O}_{2}$ in the presence of CNT were performed following the procedure described in the methodology. The replicated tests demonstrated that the process is reproducible in terms of SMX removal and the small differences observed in the early stages are negligible.

$\mathrm{CNT}, \mathrm{Fe} / \mathrm{CNT}$, and $\mathrm{TiO}_{2} / \mathrm{CNT}$ catalysts were selected for cyclic experiments of photocatalytic ozonation. Three cycles were performed, and after each cycle, the final solution was filtered, and the retained catalyst was dried for $24 \mathrm{~h}$ at $100{ }^{\circ} \mathrm{C}$. No significant differences were observed in terms of SMX removal as can be seen in Figure 7a,c,e, whereas some differences were observed in terms of TOC removal as shown in Figure $7 \mathrm{~b}, \mathrm{~d}$,f. In the case of $\mathrm{CNT}$, a significant decrease was observed between the first and second cycle, and this decline may be due to the introduction of oxygenated groups on the CNT surface promoted by $\mathrm{O}_{3}$ and/or $\mathrm{H}_{2} \mathrm{O}_{2}[2,4,7]$. Oxygenated groups reduce the electron density on the $\mathrm{CNT}$ surface, decreasing $\mathrm{O}_{3}$ decomposition in oxidizing radicals and the degradation of organic pollutants becomes less efficient $[12,14]$. For $\mathrm{Fe} / \mathrm{CNT}$ and $\mathrm{TiO}_{2} / \mathrm{CNT}$, the differences in TOC removal are less significant over the three cycles which can be explained by the great stability of these materials. In the case of $\mathrm{Fe} / \mathrm{CNT}$, the stability of $\mathrm{CNT}$ is increased by the formation of $\mathrm{Fe}-\mathrm{O}-\mathrm{C}$ bonds during calcination of the catalyst [39]. The $\mathrm{TiO}_{2} / \mathrm{CNT}$ composite does not suffer significant surface changes because it has a small content of $\mathrm{CNT}(15 \%)$ and $\mathrm{TiO}_{2}$ is highly stable. 

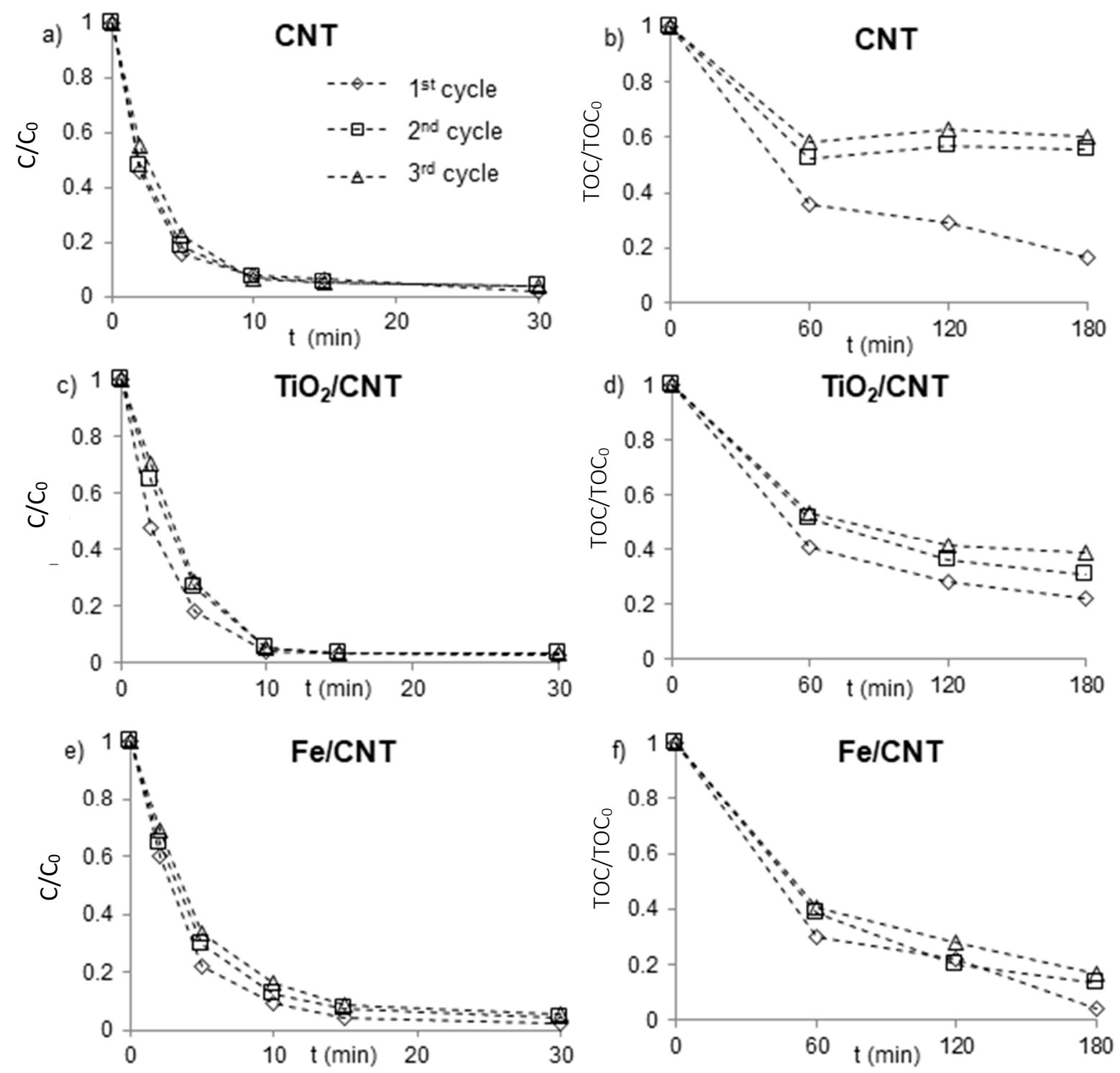

Figure 7. Dimensionless SMX $(\mathbf{a}, \mathbf{c}, \mathbf{e})$ and TOC $(\mathbf{b}, \mathbf{d}, \mathbf{f})$ concentration during reutilization experiments of photocatalytic ozonation with $\mathrm{H}_{2} \mathrm{O}_{2}\left(\mathrm{~L} / \mathrm{O}_{3} / \mathrm{H}_{2} \mathrm{O}_{2}\right)$ in the presence of $\mathrm{CNT}$, $\mathrm{TiO}_{2} / \mathrm{CNT}$, and Fe/CNT.

\subsection{Toxicity Tests}

Toxicity analyses were carried out in all reaction solutions and the results expressed in percentage of inhibition effect. Figure 8 only shows the results obtained in the processes that presented the best performance in terms of TOC removal: photocatalytic ozonation (a), catalytic ozonation with $\mathrm{H}_{2} \mathrm{O}_{2}$ (b), and photocatalytic ozonation with $\mathrm{H}_{2} \mathrm{O}_{2}$ (c).

Treated solutions by photocatalytic ozonation with $\mathrm{CNT}$ and $\mathrm{TiO}_{2} / \mathrm{CNT}$ showed lower toxicity than the non-catalytic treatment. However, no system that combines ozone and light presented lower toxicity than the initial solution ( $t=0 \mathrm{~min}$ ), leading to the conclusion that the intermediate compounds formed during this process are more toxic to Vibrio fischeri bacteria than the parent compound.

In catalytic ozonation with $\mathrm{H}_{2} \mathrm{O}_{2}$, only the treated solution with $\mathrm{Fe} / \mathrm{CNT}$ presented less toxicity than the initial.

The addition of $\mathrm{H}_{2} \mathrm{O}_{2}$ in the photocatalytic ozonation has a crucial role in toxicity reduction. A significant decrease in toxicity was observed in all photocatalytic ozonation processes. The lowest toxicity was observed with the Fe/CNT catalyst that also presented the highest mineralization level $(\approx 100 \%)$. 
AOPs involve very complex reactions. Although photocatalytic ozonation with CNT presents $93 \%$ of mineralization, its final solution had high toxicity (approximately $40 \%$ of inhibition effect). On the other hand, catalytic ozonation with $\mathrm{H}_{2} \mathrm{O}_{2}$ and Fe/CNT achieved just 76\% of TOC removal, a low level if compared with other reactions, even though, it also achieved low toxicity ( $8 \%$ of inhibition effect). This can be explained by different reaction mechanisms that may occur, leading to the formation of other non-detected products. These intermediates may have a small amount of carbon having a low contribution in TOC quantification; however, they can be very toxic.
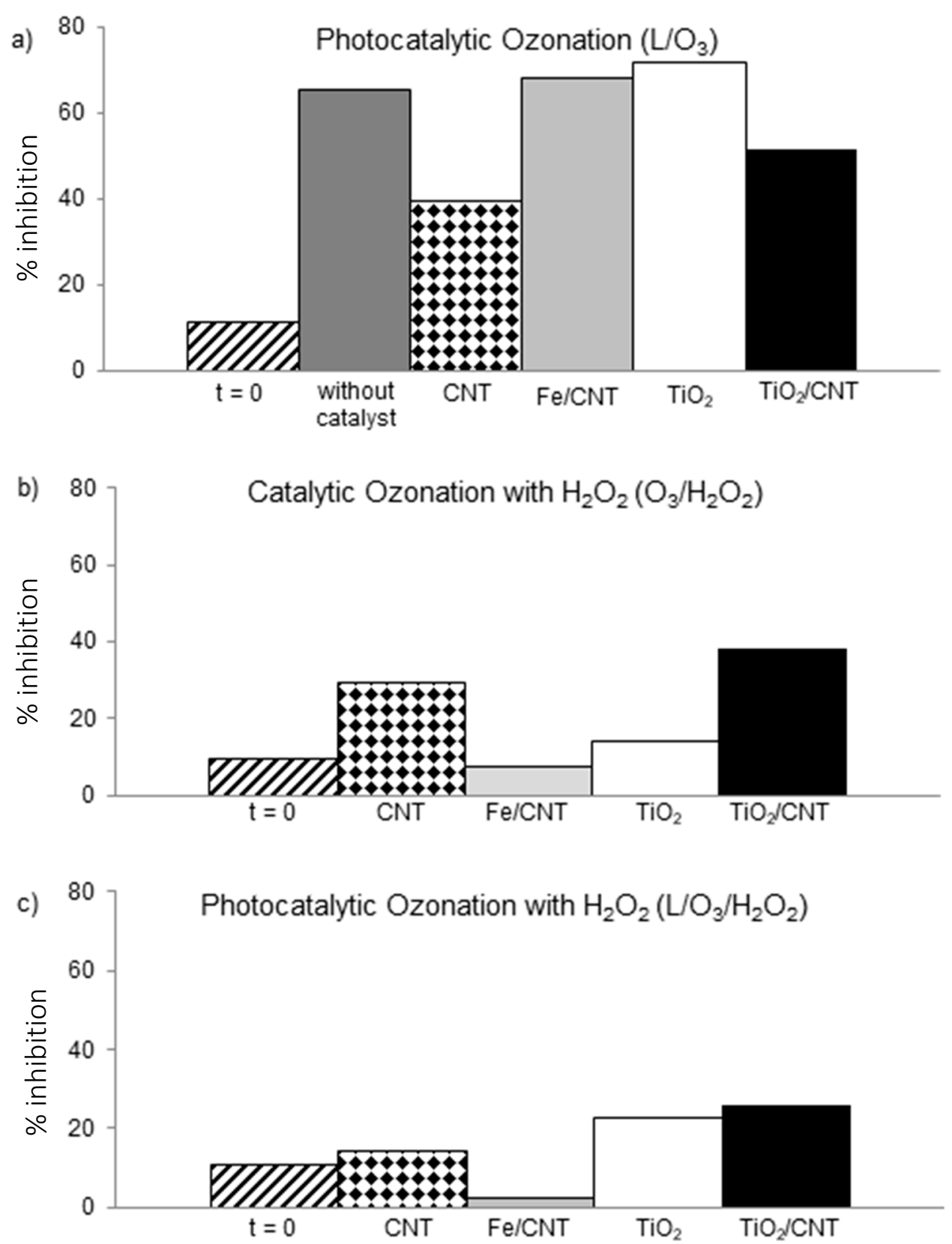

Figure 8. Light emission inhibition of Vibrio fischeri bacteria when submitted to samples resulting from the treatment (after $180 \mathrm{~min}$ ) of SMX by photocatalytic ozonation (a), catalytic ozonation with $\mathrm{H}_{2} \mathrm{O}_{2}$ (b), and photocatalytic ozonation with $\mathrm{H}_{2} \mathrm{O}_{2}$ (c). 


\section{Conclusions}

The combination of advanced oxidation processes and catalysts was advantageous for sulfamethoxazole degradation, and the most promising catalysts are CNT and Fe/CNT. Photocatalytic ozonation in the presence of CNT removed all SMX in 15 min and presented high mineralization, removing $93 \%$ of TOC after $3 \mathrm{~h}$ of reaction. Photocatalytic ozonation with $\mathrm{H}_{2} \mathrm{O}_{2}$ in the presence of $\mathrm{Fe} / \mathrm{CNT}$ totally degraded SMX after $30 \mathrm{~min}$ of reaction and showed significant improvements in terms of TOC and toxicity removal, reaching total mineralization and almost complete toxicity removal after $3 \mathrm{~h}$ of reaction.

The presence of Fe/CNT in photocatalysis, catalytic ozonation with $\mathrm{H}_{2} \mathrm{O}_{2}$, and photocatalytic ozonation with $\mathrm{H}_{2} \mathrm{O}_{2}$ reduced the toxicity of the initial solution, probably due to the formation of less toxic intermediates and a high mineralization degree. The reutilization of $\mathrm{CNT}, \mathrm{Fe} / \mathrm{CNT}$, and $\mathrm{TiO}_{2} / \mathrm{CNT}$ samples did not change SMX degradation kinetics, but, concerning TOC removal, a significant decrease was observed between the first and second cycle with the CNT catalyst probably due to the introduction of oxygenated groups on the catalyst surface.

The photocatalytic ozonation with CNT quickly degraded SMX and had high mineralization, but the treated solution presented toxic compounds. On the other hand, the photocatalytic ozonation with $\mathrm{H}_{2} \mathrm{O}_{2}$ and $\mathrm{Fe} / \mathrm{CNT}$ achieved full mineralization and low toxicity, which makes additional treatments unnecessary. However, considering economic terms, photocatalytic ozonation with CNT is more advantageous since it is not necessary to add $\mathrm{H}_{2} \mathrm{O}_{2}$ and prepare the supported catalyst.

Author Contributions: Conceptualization and supervision, O.S.G.P.S. and C.A.O.; investigation, J.M.; resources, discussion of the results, and review of the final manuscript, M.F.R.P. and J.L.F.; writing一 original draft preparation, J.M.; writing-review and editing, O.S.G.P.S. and C.A.O.

Funding: This work is a result of: Project “AIProcMat@N2020_Advanced Industrial Processes and Materials for a Sustainable Northern Region of Portugal 2020", with the reference NORTE-01-0145-FEDER-000006, supported by Norte Portugal Regional Operational Programme (NORTE 2020), under the Portugal 2020 Partnership Agreement, through the European Regional Development Fund (ERDF); Associate Laboratory LSRE-LCM-UID/EQU/50020/2019 and project POCI-01-0145-FEDER-031337—funded by national funds through FCT/MCTES (PIDDAC).

Acknowledgments: Jessica Martini acknowledges Professor Elvis Carissimi from Departamento de Engenharia Sanitária e Ambiental da Universidade Federal de Santa Maria (UFSM/CT).

Conflicts of Interest: The authors declare no conflict of interest.

\section{References}

1. Ikehata, K.; Jodeiri Naghashkar, N.; Gamal El-Din, M. Degradation of aqueous pharmaceuticals by ozonation and advanced oxidation processes: A review. Ozone Sci. Eng. 2006, 28, 353-414. [CrossRef]

2. Rivera-Utrilla, J.; Sánchez-Polo, M. Ozonation of 1,3,6-naphthalenetrisulphonic acid catalysed by activated carbon in aqueous phase. Appl. Catal. B Environ. 2002, 39, 319-329. [CrossRef]

3. Faria, P.C.C.; Órfão, J.J.M.; Pereira, M.F.R. Activated carbon catalytic ozonation of oxamic and oxalic acids. Appl. Catal. B Environ. 2008, 79, 237-243. [CrossRef]

4. Gonçalves, A.G.; Figueiredo, J.L.; Órfão, J.J.M.; Pereira, M.F.R. Influence of the surface chemistry of multi-walled carbon nanotubes on their activity as ozonation catalysts. Carbon 2010, 48, 4369-4381. [CrossRef]

5. Gonçalves, A.G.; Órfão, J.J.M.; Pereira, M.F.R. Catalytic ozonation of sulphamethoxazole in the presence of carbon materials: Catalytic performance and reaction pathways. J. Hazard. Mater. 2012, 239, 167-174. [CrossRef] [PubMed]

6. Messele, S.A.; Soares, O.S.G.P.; Órfão, J.J.M.; Bengoa, C.; Font, J. Zero-valent iron supported on nitrogen-doped carbon xerogel as catalysts for the oxidation of phenol by fenton-like system. Environ. Technol. 2018, 39, 2951-2958. [CrossRef] [PubMed]

7. Restivo, J.; Rocha, R.P.; Silva, A.M.T.; Órfão, J.J.M.; Pereira, M.F.R.; Figueiredo, J.L. Catalytic performance of heteroatom-modified carbon nanotubes in advanced oxidation processes. Chin. J. Catal. 2014, 35, 896-905. [CrossRef] 
8. Sánchez-Polo, M.; von Gunten, U.; Rivera-Utrilla, J. Efficiency of activated carbon to transform ozone into $\mathrm{OH}$ radicals: Influence of operational parameters. Water Res. 2005, 39, 3189-3198. [CrossRef]

9. Alvárez, P.M.; García-Araya, J.F.; Beltrán, F.J.; Giráldez, I.; Jaramillo, J.; Gómez-Serrano, V. The influence of various factors on aqueous ozone decomposition by granular activated carbons and the development of a mechanistic approach. Carbon 2006, 44, 3102-3112. [CrossRef]

10. Legube, B.; Karpel Vel Leitner, N. Catalytic ozonation: A promising advanced oxidation technology for water treatment. Catal. Today 1999, 53, 61-72. [CrossRef]

11. Pereira, M.F.R.; Gonçalves, A.G.; Órfão, J.J.M. carbon materials as catalysts for the ozonation of organic pollutants in water. Boletín del Grupo Español del Carbón 2014, 31, 18-24.

12. Herbst, M.H.; Macêdo, M.I.F.; Rocco, A.M. Tecnologia dos nanotubos de carbono: Tendências e perspectivas de uma área multidisciplinar. Química Nova 2004, 27, 986-992. [CrossRef]

13. Bhatkhande, D.S.; Pangarkar, V.G.; Beenackers, A.A.C.M. Photocatalytic degradation for environmental applications-A review. J. Chem. Technol. Biotechnol. 2002, 77, 102-116. [CrossRef]

14. Elmolla, E.S.; Chaudhuri, M. Photocatalytic degradation of amoxicillin, ampicillin and cloxacillin antibiotics in aqueous solution using $\mathrm{UV} / \mathrm{TiO}_{2}$ and $\mathrm{UV} / \mathrm{H}_{2} \mathrm{O}_{2} / \mathrm{TiO}_{2}$ photocatalysis. Desalination 2010, 252, 46-52. [CrossRef]

15. Agustina, T.E.; Ang, H.M.; Vareek, V.K. A review of synergistic effect of photocatalysis and ozonation on wastewater treatment. J. Photochem. Photobiol. C Photochem. Rev. 2005, 6, 264-273. [CrossRef]

16. Orge, C.A.; Pereira, M.F.R.; Faria, J.L. Photocatalytic ozonation of model aqueous solutions of oxalic and oxamic acids. Appl. Catal. B Environ. 2015, 174, 113-119. [CrossRef]

17. Di Paola, A.; García-López, E.; Marcì, G.; Palmisano, L. A survey of photocatalytic materials for environmental remediation. J. Hazard. Mater. 2012, 211, 3-29. [CrossRef] [PubMed]

18. Marques, R.R.N.; Sampaio, M.J.; Carrapiço, P.M.; Silva, C.G.; Morales-Torres, S.; Dražić, G.; Faria, J.L.; Silva, A.M.T. Photocatalytic degradation of caffeine: Developing solutions for emerging pollutants. Catal. Today 2013, 209, 108-115. [CrossRef]

19. Zhou, W.; Pan, K.; Qu, Y.; Sun, F.; Tian, C.; Ren, Z.; Tian, G.; Fu, H. Photodegradation of organic contamination in wastewaters by bonding $\mathrm{TiO}_{2} /$ single-walled carbon nanotube composites with enhanced photocatalytic activity. Chemosphere 2010, 81, 555-561. [CrossRef]

20. Cao, Q.; Yu, Q.; Connell, D.W.; Yu, G. Titania/carbon nanotube composite $\left(\mathrm{TiO}_{2} / \mathrm{CNT}\right)$ and its application for removal of organic pollutants. Clean. Technol. Environ. 2013, 15, 871-880. [CrossRef]

21. Onotri, L.; Race, M.; Clarizia, L.; Guida, M.; Alfè, M.; Andreozzi, R.; Marotta, R. Solar photocatalytic processes for treatment of soil washing wastewater. Chem. Eng. J. 2017, 318, 10-18. [CrossRef]

22. Mehrjouei, M.; Müller, S.; Möller, D. A review on photocatalytic ozonation used for the treatment of water and wastewater. Chem. Eng. J. 2015, 263, 209-219. [CrossRef]

23. Neimann, K.; Neumann, R. Electrophilic activation of hydrogen peroxide: Selective oxidation reactions in perfluorinated alcohol solvents. Org. Lett. 2000, 2, 2861-2863. [CrossRef] [PubMed]

24. Legrini, O.; Oliveros, E.; Braun, A.M. Photochemical processes for water treatment. Chem. Rev. 1993, 93, 671-698. [CrossRef]

25. Malato, S.; Blanco, J.; Vidal, A.; Alarcón, D.; Maldonado, M.I.; Cáceres, J.; Gernjak, W. Applied studies in solar photocatalytic detoxification: An overview. Sol. Energy 2003, 75, 329-336. [CrossRef]

26. Gonçalves, A.G.; Órfão, J.J.M.; Pereira, M.F.R. Ozonation of sulfamethoxazole promoted by MWCNT. Catal. Commun. 2013, 35, 82-87. [CrossRef]

27. Ribeiro, C.; Ribeiro, A.R.; Tiritan, M.E. Priority substances and emerging organic pollutants in portuguese aquatic environment: A review. Rev. Environ. Contam. Toxicol. 2015, 238, 1-44.

28. Hu, L.; Flanders, P.M.; Miller, P.L.; Strathmann, T.J. Oxidation of sulfamethoxazole and related antimicrobial agents by $\mathrm{TiO} 2$ photocatalysis. Water Res. 2007, 41, 2612-2626. [CrossRef]

29. González, O.; Sans, C.; Esplugas, S. Sulfamethoxazole abatement by photo-fenton: Toxicity, inhibition and biodegradability assessment of intermediates. J. Environ. Chem. Eng. 2007, 146, 459-464.

30. Bila, D.M.; Dezotti, M. Farmacos no meio ambiente. Química Nova 2003, 26, 523-530. [CrossRef]

31. Gaffney, V.D.J.; Cardoso, V.V.; Rodrigues, A.; Ferreira, E.; Benoliel, M.J.; Almeida, C.M.M. Análise de fármacos em águas por SPE-UPLC-ESI-MS/MS. Química Nova 2010, 408, 5513-5520. [CrossRef]

32. Madureira, T.V.; Barreiro, J.C.; Rocha, M.J.; Rocha, E.; Cass, Q.B.; Tiritan, M.E. Spatiotemporal distribution of pharmaceuticals in the Douro River estuary (Portugal). Sci. Total Environ. 2010, 408, 5513-5520. [CrossRef] [PubMed] 
33. Martini, J.; Orge, C.A.; Faria, J.L.; Pereira, M.F.R.; Soares, O.S.G.P. Sulfamethoxazole degradation by combination of advanced oxidation processes. J. Environ. Chem. Eng. 2018, 6, 4054-4060. [CrossRef]

34. Wang, W.; Silva, C.G.; Faria, J.L. Photocatalytic degradation of Chromotrope 2R using nanocrystalline $\mathrm{TiO}_{2}$ /activated-carbon composite catalysts. Appl. Catal. B Environ. 2007, 70, 470-478. [CrossRef]

35. Silva, C.G.; Faria, J.L. Effect of key operational parameters on the photocatalytic oxidation of phenol by nanocrystalline sol-gel $\mathrm{TiO}_{2}$ under UV irradiation. J. Mol. Catal. A Chem. 2009, 305, 147-154. [CrossRef]

36. Orge, C.A.; Soares, O.S.G.P.; Faria, J.L.; Pereira, M.F.R. Synthesis of $\mathrm{TiO}_{2}$-Carbon Nanotubes through ball-milling method for mineralization of oxamic acid (OMA) by photocatalytic ozonation. J. Environ. Chem. Eng. 2017, 5, 5599-5607. [CrossRef]

37. International Organization for Standardization. I.D-Determination of the Inhibitory Effect of Water Samples on the Light Emission of Vibrio Fischeri (Luminescent bacteria Test); ISO 11348-3; ISO: Geneva, Switzerland, 2007.

38. Beltrán, F.J.; Rivas, F.J.; Montero-de-Espinosa, R. Iron type catalysts for the ozonation of oxalic acid in water. Water Res. 2005, 39, 3553-3564. [CrossRef] [PubMed]

39. Zhang, S.; Wang, D.; Quan, X.; Zhou, L.; Zhang, X. Multi-walled carbon nanotubes immobilized on zero-valent iron plates (Fe0-CNTs) for catalytic ozonation of methylene blue as model compound in a bubbling reactor. Sep. Purif. Technol. 2013, 116, 351-359. [CrossRef]

40. Abellán, M.N.; Giménez, J.; Esplugas, S. Photocatalytic degradation of antibiotics: The case of sulfamethoxazole and trimethoprim. Catal. Today 2009, 144, 131-136. [CrossRef]

41. Baran, W.; Adamek, E.; Sobczak, A.; Makowski, A. Photocatalytic degradation of sulfa drugs with $\mathrm{TiO}_{2}, \mathrm{Fe}$ salts and $\mathrm{TiO}_{2} / \mathrm{FeCl}_{3}$ in aquatic environment-Kinetics and degradation pathway. Appl. Catal. B Environ. 2009, 90, 516-525. [CrossRef]

42. Su, Y.-F.; Wang, G.-B.; Kuo, D.T.F.; Chang, M.-L.; Shih, Y.-H. Photoelectrocatalytic degradation of the antibiotic sulfamethoxazole using $\mathrm{TiO}_{2} / \mathrm{Ti}$ photoanode. Appl. Catal. B Environ. 2016, 186, 184-192. [CrossRef]

43. Czech, B.; Oleszczuk, P.; Wiącek, A.E.; Barczak, M. Water treatment by $\mathrm{H}_{2} \mathrm{O}_{2}$ and/or UV affects carbon nanotube (CNT) properties and fate in water and tannic acid solution. Environ. Sci. Pollut. Res. Int. 2015, 22, 20198-20206. [CrossRef] [PubMed]

44. Mackul'ak, T.; Takáčová, A.; Gál, M.; Marton, M.; Ryba, J. PVC degradation by Fenton reaction and biological decomposition. Polym. Degrad. Stab. 2015, 120, 226-231. [CrossRef]

45. Melo, S.A.S.; Trovó, A.G.; Bautitz, I.R.; Nogueira, R.F.P. Degradação de fármacos residuais por processos oxidativos avançados. Química Nova 2009, 32, 188-197. [CrossRef]

46. Pera-Titus, M.; García-Molina, V.; Baños, M.A.; Giménez, J.; Esplugas, S. Degradation of chlorophenols by means of advanced oxidation processes: A general review. Appl. Catal. B Environ. 2004, 47, 219-256. [CrossRef]

47. Orge, C.A.; Faria, J.L.; Pereira, M.F.R. Removal of oxalic acid, oxamic acid and aniline by a combined photolysis and ozonation process. Environ. Technol. 2015, 36, 1075-1083. [CrossRef] [PubMed]

48. Pimentel, M.; Oturan, N.; Dezotti, M.; Oturan, M.A. Phenol degradation by advanced electrochemical oxidation process electro-Fenton using a carbon felt cathode. Appl. Catal. B Environ. 2008, 83, 140-149. [CrossRef]

49. Guinea, E.; Arias, C.; Cabot, P.L.; Garrido, J.A.; Rodríguez, R.M.; Centellas, F.; Brillas, E. Mineralization of salicylic acid in acidic aqueous medium by electrochemical advanced oxidation processes using platinum and boron-doped diamond as anode and cathodically generated hydrogen peroxide. Water Res. 2008, 42, 499-511. [CrossRef]

50. Isarain-Chávez, E.; Rodríguez, R.M.; Cabot, P.L.; Centellas, F.; Arias, C.; Garrido, J.A.; Brillas, E. Degradation of pharmaceutical beta-blockers by electrochemical advanced oxidation processes using a flow plant with a solar compound parabolic collector. Water Res. 2011, 45, 4119-4130. [CrossRef]

51. Mahmoodi, N.M. Photocatalytic ozonation of dyes using multiwalled carbon nanotube. J. Mol. Catal. A Chem. 2013, 366, 254-260. [CrossRef]

(C) 2019 by the authors. Licensee MDPI, Basel, Switzerland. This article is an open access article distributed under the terms and conditions of the Creative Commons Attribution (CC BY) license (http://creativecommons.org/licenses/by/4.0/). 